\title{
A new genus and species of isanthid sea anemone (Cnidaria: Anthozoa: Actiniaria) from Chilean Patagonia, Anthoparactis fossii n. gen. et sp
}

\author{
Verena Häussermann • Estefanía Rodríguez
}

Received: 13 January 2014/Revised: 7 May 2014/ Accepted: 12 May 2014/Published online: 2 July 2014

(C) Springer-Verlag Berlin Heidelberg and AWI 2014

\begin{abstract}
We describe a new genus and species of sea anemone from Chilean Patagonia. Anthoparactis fossii n. gen. et sp. adds another acontiate genus and species to the family Isanthidae Carlgren, 1938. Anthoparactis n. gen. differs from the other isanthid genera in having the same number of mesenteries distally and proximally, acontia with basitrichs only, and a column with verrucae distally. Anthoparactis fossii n. sp. differs from the most similar species, Isoparactis fionae Lauretta et al., 2013, in the number of cycles of mesenteries and tentacles, structures of the column, colour pattern of the oral disc, cnidae, and geographical distribution. Isanthidae now includes seven genera and 11 species.
\end{abstract}

Keywords Isanthidae $\cdot$ Acontia $\cdot$ Isoparactis $\cdot$ Northern Patagonian Zone $\cdot$ Shallow water

\section{Introduction}

We describe Anthoparactis fossii n. gen. et sp. from shallow water of the channels of the Northern Patagonian Zone (Chile) based on 17 specimens collected in 2005, 2011 and

Communicated by H.-D. Franke.

V. Häussermann $(\square)$

Facultad de Recursos Naturales, Escuela de Ciencias del Mar, Pontificia Universidad Católica de Valparaíso, Avda. Brasil 2950, Valparaiso, Chile

e-mail: v.haussermann@gmail.com

E. Rodríguez

Division of Invertebrate Zoology, American Museum of Natural History, Central Park West at 79th Street, New York, NY 10024, USA
2014. Anthoparactis fossii n. gen. et sp. represents the fourth acontiate species within Isanthidae Carlgren, 1938, and the third isanthid sea anemone described from Chilean Patagonia. The other two Chilean species are Isoparactis fabiani (Häussermann and Försterra, 2008) and Isoparactis fionae Lauretta et al., 2013; the latter one being the most similar within the family to A. fossii n. gen. et sp. Family Isanthidae now contains seven genera and 11 species, eight of which inhabit the southern hemisphere. The membership and systematics of the family have been discussed in detail (see Häussermann and Försterra 2008; Lauretta et al. 2013).

\section{Materials and methods}

Between 1998 and early 2014, we observed, collected, examined and preserved nearly 2000 specimens of shallow water (to $40 \mathrm{~m}$ depth) actiniarians and corallimorpharians at nearly 300 sites in the Chilean fjord region from Puerto Montt $\left(41^{\circ} 30^{\prime} \mathrm{S}\right)$ to Navarino Island, and the Beagle Channel $\left(55^{\circ} \mathrm{S}\right)$. At four of these sites, in the Northern Patagonian Zone, VH and Günter Försterra collected 16 specimens of $A$. fossii n. gen. et sp. and documented specimens at two additional sites (Fig. 1). We relaxed the specimens with menthol crystals for a couple of hours and then fixed them in 7-10\% seawater formalin. After a few months, we transferred them to $70 \%$ ethanol for long-term storage. Additionally, we fixed four of the specimens in 96-100\% ethanol for molecular studies. We examined specimens as a whole and dissected all. For histological examination, we embedded parts of three specimens in paraffin, sectioned them at 5-10 $\mu \mathrm{m}$, and stained them with Azocarmin Triple Stain (Humason 1967) or Ramón y Cajal's Triple Stain (Gabe 1968). We analysed the 
distribution of cnidae in the tissues from up to four specimens using DIC light microscopy $(1,000 \times$ magnification, oil immersion) and haphazardly measured and photographed 40 non-fired capsules of each cnida type (whenever possible). Mean and standard deviation are provided to give an estimate of size distribution. Cnidae nomenclature follows Mariscal (1974).

The studied material has been deposited in the Zoologische Staatssammlung München (ZSM), Germany, in the American Museum of Natural History (AMNH), USA, and in the Museo de Zoología de la Universidad de Concepción (MZUC-UCCC), Chile.

Systematics

Suborder ENTHEMONAE Rodríguez and Daly in Rodríguez et al., 2014

Superfamily METRIDIOIDEA Carlgren, 1893

Family ISANTHIDAE Carlgren, 1938

Diagnosis (Lauretta et al. 2013), modification in bold

Metridioidea with basilar muscles and mesogleal marginal sphincter. Mesenteries divisible into macro- and

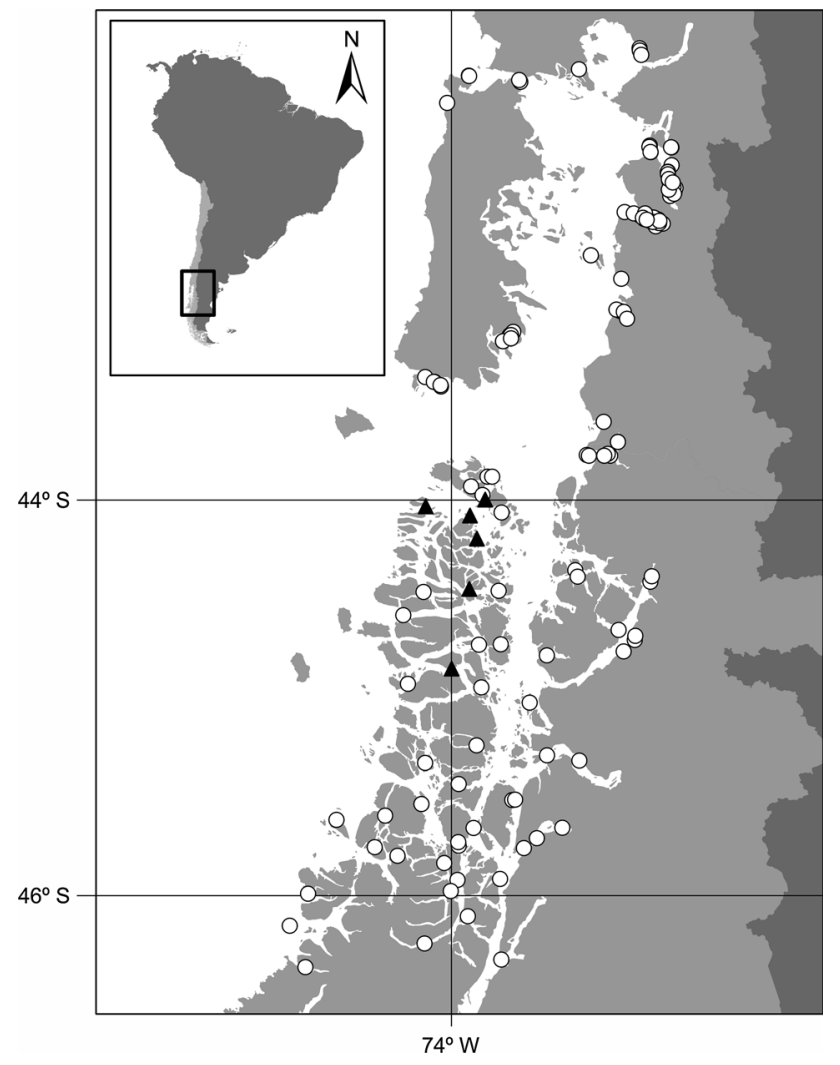

Fig. 1 Geographical distribution of Anthoparactis fossii n. gen. et sp. Black triangles indicate localities where A. fossii was found; white circles indicate those localities where A. fossii was not found. Light shading corresponds to Chile micro-cnemes. Retractor muscles strongly restricted (reniform) to almost circumscribed. Acontia, if present, with basitrichs and in some species with microbasic $p$-amastigophores. Cnidom: spirocysts, basitrichs, holotrichs and microbasic $p$-amastigophores.

Included genera. Anthoparactis n. gen.; Isoparactis Stephenson, 1920; Isanthus Carlgren, 1938; Paraisanthus Sanamyan and Sanamyan, 1998; Eltaninactis Dunn, 1983; Zaolutus Hand, 1955; Austroneophellia Zamponi, 1978.

Genus Anthoparactis n. gen.

Diagnosis

Isanthidae with definite pedal disc. Column with verrucae in distal half, absent in uppermost border. Margin rather distinct, without fosse. Tentacles short. Longitudinal muscles of tentacles and radial muscles of oral disc ectodermal. Two well-developed siphonoglyphs attached to directive mesenteries. Same number of mesenteries distally and proximally. Six perfect pairs of mesenteries, fertile, with strong, circumscript retractor muscles. Basilar muscles well developed. Acontia present with basitrichs only. Cnidom: spirocysts, basitrichs, and microbasic $p$-amastigophores.

Type species. Anthoparactis fossii n. gen. et sp.

Etymology

The generic name is composed of "Antho", a common prefix for actiniarian genera meaning flower, and the genus name "Paractis" because Anthoparactis n. gen. most closely resembles the existing genus Isoparactis.

Anthoparactis fossii n. sp. (Figs. 1, 2, 3, 4; Table 1).

\section{Type material}

Holotype (ZSM 20140173): Isla Laurel W, Guaitecas Archipielago, Chile, $\left(44^{\circ} 00^{\prime} 33^{\prime \prime} \mathrm{S}, 73^{\circ} 45^{\prime} 35^{\prime \prime} \mathrm{W}\right) 7$ March 2005 , $13 \mathrm{~m}, 1$ specimen fixed in $10 \%$ formalin and stored in $70 \%$ ethanol. Paratypes: Isla Laurel W, Guaitecas Archipielago, Chile, $\left(44^{\circ} 00^{\prime} 33^{\prime \prime} \mathrm{S}, 73^{\circ} 45^{\prime} 35^{\prime \prime} \mathrm{W}\right), 7$ March 2005, $13 \mathrm{~m}, 2.5$ specimens fixed in $10 \%$ formalin and stored in $70 \%$ ethanol (ZSM 20140174), two histological slides of transverse and longitudinal sections (ZSM 20140175/1-5), Isla Laurel W, Guaitecas Archipielago, Chile, $\left(44^{\circ} 00^{\prime} 33^{\prime \prime} \mathrm{S}, 73^{\circ} 45^{\prime} 35^{\prime \prime} \mathrm{W}\right), 7$ March 2005, 13 m, 2.5 specimens fixed in $10 \%$ formalin and stored in $70 \%$ ethanol (AMNH-5347), five histological slides of transverse and longitudinal sections, respectively, (AMNH5347.1-AMNH-5347.10), and 2 specimens fixed in $96 \%$ ethanol (AMNH-5348); Isla Llenihuenu, Chonos 


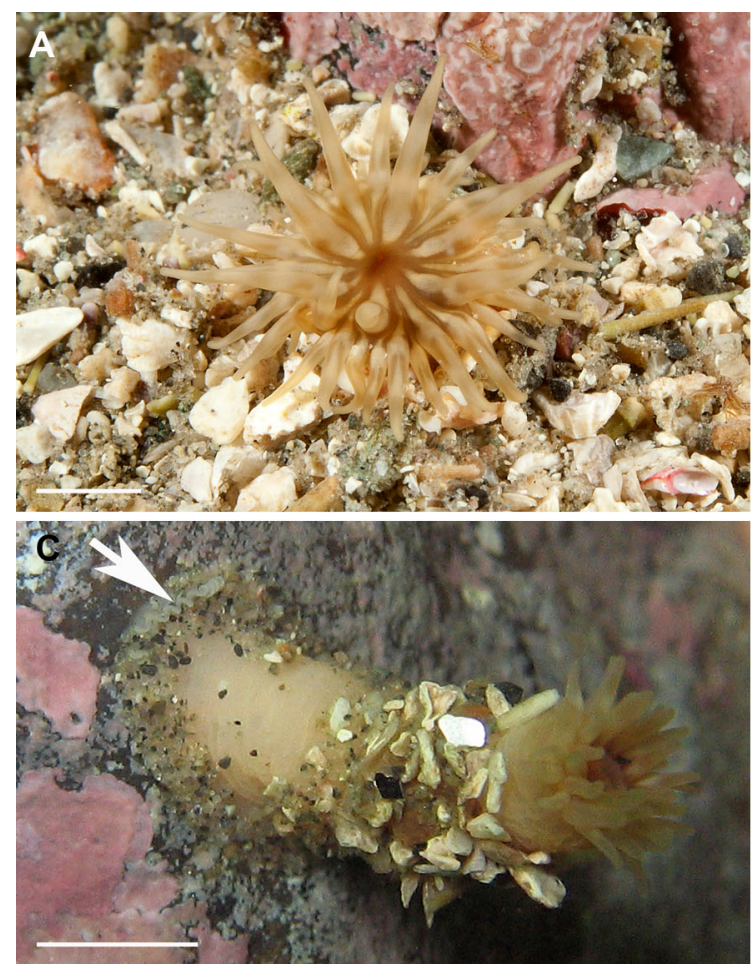

Fig. 2 External anatomy of Anthoparactis fossii n. gen. et sp. a, b Anthoparactis fossii in its habitat with only oral disc and tentacles visible. c Specimen still attached to the stone with which it was

Archipielago, Chile, $\left(44^{\circ} 02^{\prime} 06^{\prime \prime} \mathrm{S}, 74^{\circ} 11^{\prime} 22^{\prime \prime} \mathrm{W}\right), 24$ November $2011,5.5 \mathrm{~m}, 3$ specimens fixed in $10 \%$ formalin and stored in $70 \%$ ethanol (ZSM 20140176) and 0.5 specimens fixed in $100 \%$ ethanol (ZSM 20140177); Isla Llenihuenu, Chonos Archipielago, Chile, $\left(44^{\circ} 02^{\prime} 06^{\prime \prime} \mathrm{S}, 74^{\circ} 11^{\prime} 22^{\prime \prime} \mathrm{W}\right), 24$ November 2011, $5.5 \mathrm{~m}, 0.5$ specimen (second half of $\mathrm{nr}$ ZSM 20140177, see above) fixed in $100 \%$ ethanol (AMNH-5349); Isla Jorge $\left(44^{\circ} 51^{\prime} 41^{\prime \prime} \mathrm{S}, 74^{\circ} 00^{\prime} 20^{\prime \prime} \mathrm{W}\right), 22$ November $2011,18 \mathrm{~m}, 1$ specimen fixed in $10 \%$ formalin and stored in $70 \%$ ethanol (ZSM 20140178) and 1 specimen fixed in $100 \%$ ethanol (ZSM 20140179); Isla Jorge $\left(44^{\circ} 51^{\prime} 41^{\prime \prime} \mathrm{S}, \quad 74^{\circ} 00^{\prime} 20^{\prime \prime} \mathrm{W}\right), \quad 22$ November 2011, 18 m, 1 specimen fixed in $10 \%$ formalin and stored in $70 \%$ ethanol (MZUC-CCC-41743); Isla Jechica $\left(44^{\circ} 27^{\prime} 26^{\prime \prime} \mathrm{S}, 73^{\circ} 52^{\prime} 47^{\prime \prime} \mathrm{W}\right), 14$ April $2014,8 \mathrm{~m}, 1$ specimen fixed in $7 \%$ formalin (ZSM 20140180).

\section{Description}

\section{External anatomy}

Size (preserved). Oral disc 4 to $7 \mathrm{~mm}$ diameter, pedal disc 3 to $5 \mathrm{~mm}$ diameter, column 6 to $14 \mathrm{~mm}$ long and 3 to $8 \mathrm{~mm}$ diameter, tentacles 2 to $4 \mathrm{~mm}$ long.

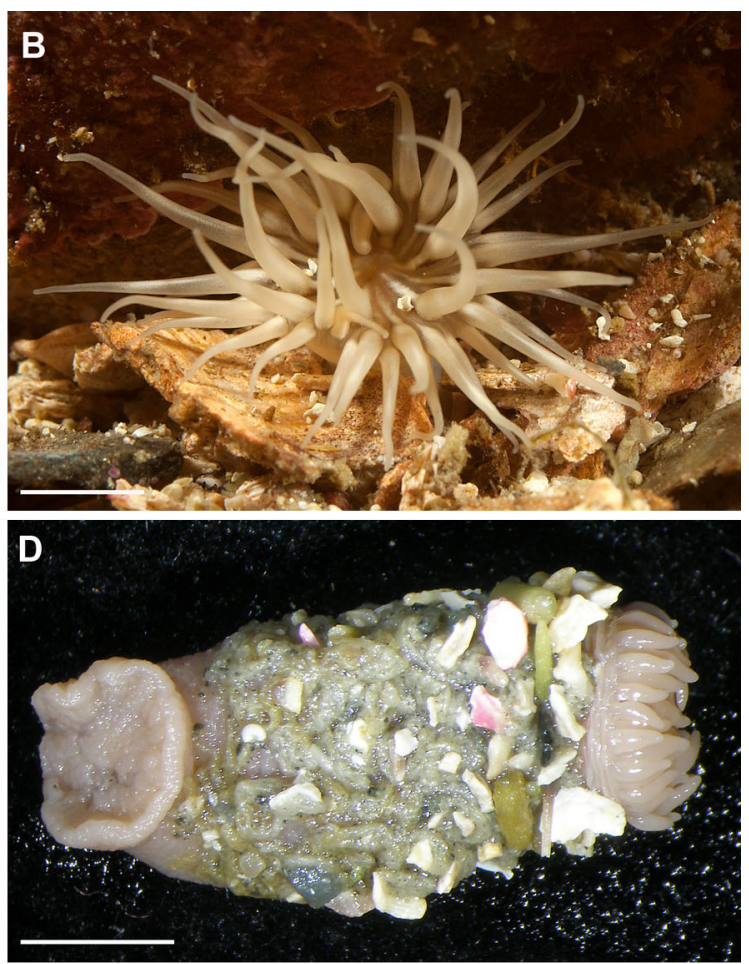

burrowed in the sandy sediment. Note acontia (arrow). d Preserved specimen. Scale bars $5 \mathrm{~mm}$

Colour (Fig. 2a, b). Oral disc brown with lighter radial bands from base of tentacles almost to mouth opening, more pronounced in first and second cycles (with broader bands corresponding to higher cycles). Actinopharynx brown. Tentacles translucent brown; in some specimens with few weak darker or lighter longitudinal lines on oral side (Fig. 2b). Column light brown (Fig. 2c), uniformly coloured or with distalmost area more intensely coloured. Preserved specimens brown.

Oral disc and tentacles. Fourty-eight tentacles hexamerously arranged in four cycles, length in extended state slightly longer than diameter of oral disc; outer tentacles slightly shorter than inner ones, on outer third to half of oral disc; inner six (first cycle) directed upward (Fig. 2b). Oral disc circular (Fig. 2a). Mouth opening central, slightly oval.

Column. In situ much higher than wide, distal half to $2 / 3$ with verrucae (Fig. 3e) in approximately 24 rows to which small grains of sand, pieces of shell and sea urchin spines are attached (Fig. 2c, d); often with ring of mucus and tiny sand grains in proximal most part. Distal most millimetres of column without attached sand and pieces of shells (Fig. 2c, d). Margin tentaculate. 

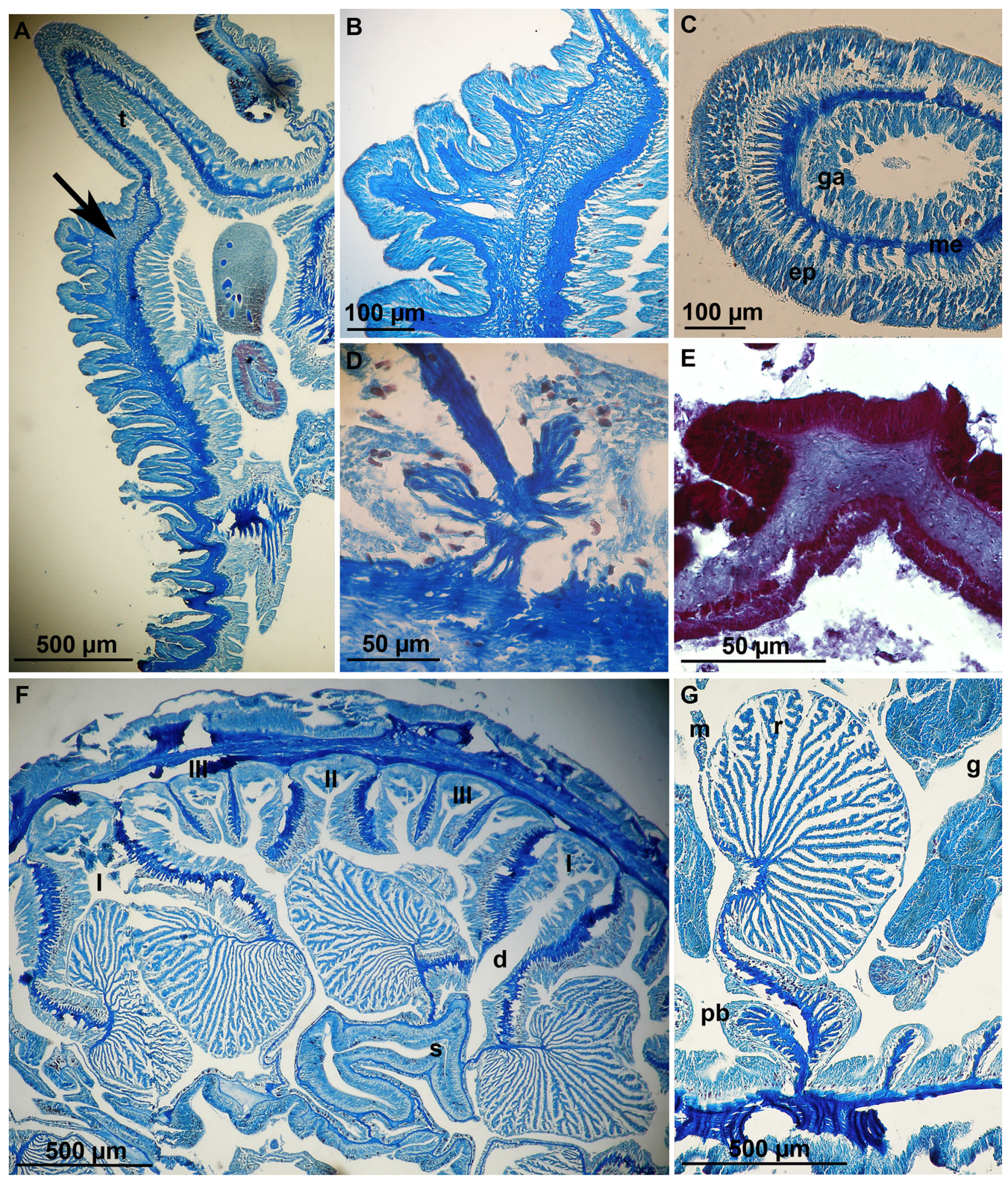

Fig. 3 Internal anatomy of Anthoparactis fossii n. gen. et $\mathrm{sp.}$ a Longitudinal section of distal part of the column showing the mesogleal marginal sphincter muscle (arrow). b Detail of marginal sphincter muscle. c Cross section of a tentacle showing the ectodermal longitudinal muscles. d Longitudinal section of the pedal disc showing the basilar muscles. e Longitudinal section of the column showing a verruca. f Cross section at the actinopharynx level showing cycles of mesenteries. $\mathbf{g}$ Detail of retractor and parietobasilar muscles. I, II and III, indicate cycles of mesenteries; I, macrocnemes; II and III, microcnemes; $d$ directives, $e p$ epidermis, $g$ reproductive tissue, $g a$ gastrodermis, $m$ mesentery, $m e$ mesogloea, $p b$ parietobasilar muscles, $r$ retractor muscle, $s$ siphonoglyph, $t$ tentacle 


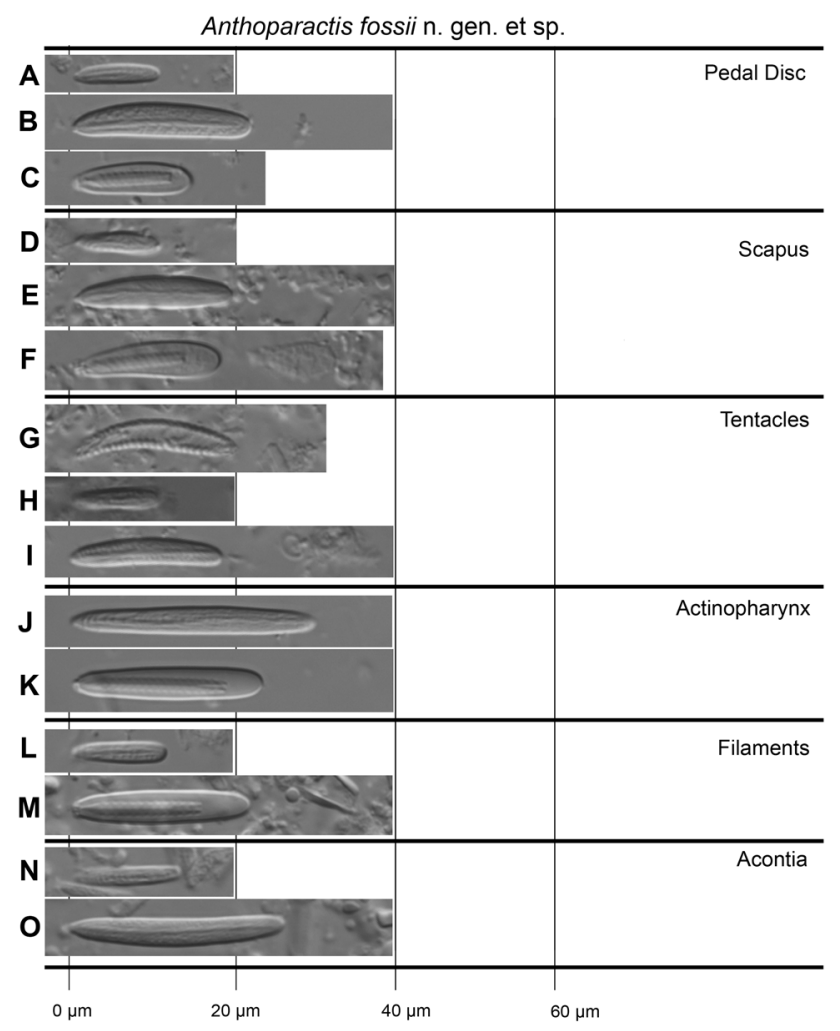

Fig. 4 Cnidae of Anthoparactis fossii n. gen. et sp. ( $a, b, d, e, h, i, j, l$, $n, o)$ Basitrichs, $(c, f, k, m)$ Microbasic $p$-amastigophores, (g) Spirocyst

Well developed; more or less circular (Fig. 2d).

\section{Internal anatomy}

Twenty-four pairs of mesenteries hexamerously arranged in three cycles; first cycle (six pairs) including directives fertile, macrocnemes with strong circumscript retractors (Fig. 3g), second and third cycle (six plus 12 pairs) sterile microcnemes without retractors (Fig. 3f). Same number of mesenteries proximally and distally. Actinopharynx deeply furrowed, with two distinct siphonoglyphs (Fig. 3f), about $1 / 3$ length of column; each attached to a pair of directives. Small round marginal stoma. Sexes separate; only male specimens observed (seven specimens studied), spermatic cysts up to $0.42 \mathrm{~mm}$ in diameter (Fig. $3 \mathrm{~g}$ ) in specimens collected in March and November; no signs of asexual reproduction. Acontia only attached to macrocnemes, coiled and relatively short, with basitrichs only. No zooxanthellae.

Strong mesogloeal marginal sphincter muscle (Fig. 3a, b), approximately half width of mesogloea, restricted to distal most part of column. Macrocneme retractors strong, circumscript (Fig. 3g). Parietobasilar muscles well developed (Fig. 3g); basilar muscles distinct (Fig. 3d). Longitudinal muscles of tentacles (Fig. 3c) and radial muscles of oral disc ectodermal. Epidermis to $0.10-0.20 \mathrm{~mm}$ thick, mesogloea to $0.1-0.12 \mathrm{~mm}$ thick, gastrodermis to $0.06-0.14 \mathrm{~mm}$ thick.

Cnidom. Spirocysts (in tentacles), basitrichs (in tentacles, scapus, actinopharynx, filaments, acontia and pedal disc), microbasic $p$-amastigophores ( $p$-rhabdoids B1 sensu Schmidt (1969) in scapus, actinopharynx, filaments and pedal disc) (Table 1).

Common name: Fossi's sand gerbera or Fossi's sand star anemone.

Etymology

The species is named after Fossi (Günter Försterra) who discovered the species in 2005 together with $\mathrm{VH}$, and collected specimens in 2011.

\section{Distribution and natural history}

Shallow subtidal to at least $18 \mathrm{~m}$ depth around relatively exposed islands in the Guaitecas and Northern Chonos Archipielagos between $44^{\circ} \mathrm{S}$ and $45^{\circ} \mathrm{S}$ approximately at Isla Laurel $\left(44^{\circ} 00^{\prime} 33^{\prime \prime} \mathrm{S}, \quad 73^{\circ} 45^{\prime} 35^{\prime \prime} \mathrm{W}\right)$, Isla Llenihuenu $\left(44^{\circ} 02^{\prime} 06^{\prime \prime} \mathrm{S}, \quad 74^{\circ} 11^{\prime} 22^{\prime \prime} \mathrm{W}\right)$, Isla Amita $\left(44^{\circ} 04^{\prime} 55^{\prime \prime} \mathrm{S}\right.$, $\left.73^{\circ} 52^{\prime} 29^{\prime \prime} \mathrm{W}\right)$, SE Point Isla Concoto $\left(44^{\circ} 12^{\prime} 20^{\prime \prime} \mathrm{S}\right.$, $\left.73^{\circ} 49^{\prime} 31^{\prime \prime} \mathrm{W}\right)$, Isla Jechica $\left(44^{\circ} 27^{\prime} 26^{\prime \prime} \mathrm{S}, 73^{\circ} 52^{\prime} 47^{\prime \prime} \mathrm{W}\right)$, Isla Jorge ( $\left.44^{\circ} 51^{\prime} 41^{\prime \prime} \mathrm{S}, 74^{\circ} 00^{\prime} 20^{\prime \prime} \mathrm{W}\right)$, Northern Patagonian Zone (Fig. 1). We did not find the species at the numerous study sites south of $45^{\circ} \mathrm{S}$ down to Navarino Island south of the Beagle Channel (Fig. 1). Specimens are burrowed in coarse sand (with broken shells and sea urchin spines) or between small rocks with only the oral disc visible on the substrate into which they retract when disturbed. The pedal disc is attached to buried stones or rock. Species not abundant and not easy to see; at the six sites, we only found few specimens sharing the habitat with Condylanthus sp., a small, unidentified burrowing anemone and an unidentified red endomyarian species.

\section{Discussion}

Generic placement of Anthoparactis fossii $\mathrm{n}$. gen. et sp

The combination of generic characteristics of Anthoparactis $\mathrm{n}$. gen. does not fit any existing genus of the family Isanthidae (see Table 2, Häussermann and Försterra 2008; Lauretta et al. 2013); the most similar genera are Isoparactis and Isanthus. Anthoparactis n. gen. can be 
Table 1 Size ranges and distribution of cnidae in Anthoparactis fossii n. gen. et sp.: mean length by mean width of capsules

\begin{tabular}{|c|c|c|c|c|c|}
\hline Categories & $\begin{array}{l}\text { Range of length and width of capsules }(\mu \mathrm{m}) \\
\text { Anthoparactis fossii } \mathrm{n} \text {. gen. et sp. }\end{array}$ & $\bar{X} \pm \mathrm{SD}$ & $S$ & $N$ & $F$ \\
\hline \multicolumn{6}{|l|}{ Pedal disc } \\
\hline Basitrichs 1 (A) & $8.0-11.0 \times 2.0-3.0$ & $9.8 \pm 0.8 \times 2.1 \pm 0.2$ & $3 / 3$ & 43 & ++ \\
\hline Basitrichs 2 (B) & $16.0-25.0 \times 3.0-4.0$ & $19.8 \pm 1.6 \times 3.9 \pm 0.3$ & $3 / 3$ & 46 & ++ \\
\hline M p-mastigophores B1 (C) & $12.0-17.0 \times 4.0-6.0$ & $14.9 \pm 1.4 \times 4.8 \pm 0.7$ & $3 / 3$ & 14 & - \\
\hline \multicolumn{6}{|l|}{ Scapus } \\
\hline Basitrichs 1 (D) & $8.0-11.0 \times 2.0-3.0$ & $10.0 \pm 0.7 \times 2.1 \pm 0.3$ & $3 / 3$ & 43 & + \\
\hline Basitrichs 2 (E) & $18.0-23.0 \times 3.0-4.0$ & $20.2 \pm 1.3 \times 4.0 \pm 0.1$ & $3 / 3$ & 71 & ++ \\
\hline M p-mastigophores B1 (F) & $13.0-19.0 \times 3.5-5.0$ & $15.7 \pm 1.6 \times 4.0 \pm 0.2$ & $3 / 3$ & 56 & ++ \\
\hline \multicolumn{6}{|l|}{ Tentacles } \\
\hline Spirocysts (G) & $13.0-26.0 \times 2.0-4.0$ & $20.9 \pm 2.9 \times 3.0 \pm 0.4$ & $3 / 3$ & 56 & ++ \\
\hline Basitrichs $1(\mathrm{H})$ & $8.0-14.0 \times 2.0-3.0$ & $11.3 \pm 1.9 \times 2.1 \pm 0.3$ & $3 / 3$ & 41 & + \\
\hline Basitrichs 2 (I) & $17.0-23.0 \times 2.0-3.0$ & $20.1 \pm 1.4 \times 3.0 \pm 0.1$ & $3 / 3$ & 50 & ++ \\
\hline \multicolumn{6}{|l|}{ Actinopharynx } \\
\hline Basitrichs (J) & $25.0-37-0 \times 3.0-4.0$ & $29.4 \pm 2.0 \times 3.0 \pm 0.2$ & $3 / 3$ & 54 & ++ \\
\hline M p-mastigophores B1 (K) & $22.0-29.0 \times 4.0-5.0$ & $25.2 \pm 1.7 \times 4.1 \pm 0.3$ & $3 / 3$ & 60 & ++ \\
\hline \multicolumn{6}{|l|}{ Filaments } \\
\hline Basitrichs (L) & $9.0-14.0 \times 1.5-3.0$ & $11.7 \pm 1.1 \times 2.1 \pm 0.4$ & $4 / 4$ & 43 & ++ \\
\hline M p-mastigophores B1 (M) & $16.0-25.0 \times 3.0-5.0$ & $22.7 \pm 1.6 \times 4.3 \pm 0.5$ & $4 / 4$ & 63 & ++ \\
\hline \multicolumn{6}{|l|}{ Acontia } \\
\hline Basitrichs $1(\mathrm{~N})$ & $8.0-16.0 \times 1.5-3.0$ & $13.0 \pm 1.6 \times 2.4 \pm 0.5$ & $2 / 3$ & 43 & + \\
\hline Basitrichs 2 (O) & $23.0-29.0 \times 3.0$ & $26.1 \pm 1.3 \times 3.0 \pm 0$ & $3 / 3$ & 65 & +++ \\
\hline
\end{tabular}

Letters next to cnidae categories correspond to images in Fig. 4

$S D$ standard deviation, $S$ ratio of number of specimens in which each cnidae was found to number of specimens examined, $N$ total number of capsules measured, $F$ Frequency, $+++=$ very common, $++=$ common, $+=$ rather common, $-=$ sporadic; $M$ Microbasic values from pooled samples.

distinguished from Isoparactis by the number of mesenteries distally and proximally, structures in the column and cnidae of the acontia. Anthoparactis n. gen. differs from Isanthus in the structures in the column, development of the marginal sphincter, shape of the retractors and presence of acontia. Compared with Paraisanthus, Anthoparactis n. gen. differs in the number of mesenteries distally and proximally, structures of the column and presence of acontia. It differs from Zaolutus in the number of tentacles, perfect and fertile mesenteries, number of mesenteries distally and proximally, number of marginal sphincters, shape of the retractors, structures of the column and presence of acontia. Anthoparactis n. gen. can be distinguished from Eltaninactis by the number of tentacles and mesenteries, development of the marginal sphincter, structures of the column and presence of acontia. The genus Austroneophellia is poorly known and the original description (only source of information available) of this genus is questionable, with several dubious statements (e.g. the marginal sphincter muscle is described as "mesogloeal, circumscribed palmate" (see Zamponi 1978), a non-existing combination).
The relationship between the number of mesenteries distally and proximally, structures of the column and cnidae of the acontia might all be considered generic-level characters for Isanthidae (Lauretta et al. 2013) and thus warrant the erection of a new genus.

\section{Differential diagnosis of Anthoparactis fossii n. sp}

Anthoparactis fossii n. gen. et sp. resembles morphologically more closely Isoparactis fionae; this relationship is further supported by mitochondrial DNA sequences (ER unpub.). Both A. fossii n. gen. et sp. and I. fionae possess adhesive structures on the column, whereas I. fabiani and $I$. ferax (Stuckey, 1909) have a smooth column. The columnar structures of $I$. fionae are described as adhesive rugae (see Fig. 3d in Lauretta et al. 2013) and those of A. fossii n. gen. et sp. as verrucae (Fig 3e). Both columnar structures are adhesive; however, in contrast to rugae, the epidermis of verrucae is modified (Stephenson 1928, 1935). Although in both species we could not detect cinclides (present in $I$. ferax), we could observe an acontium on the proximal column of an uninjured specimen of both species (see 


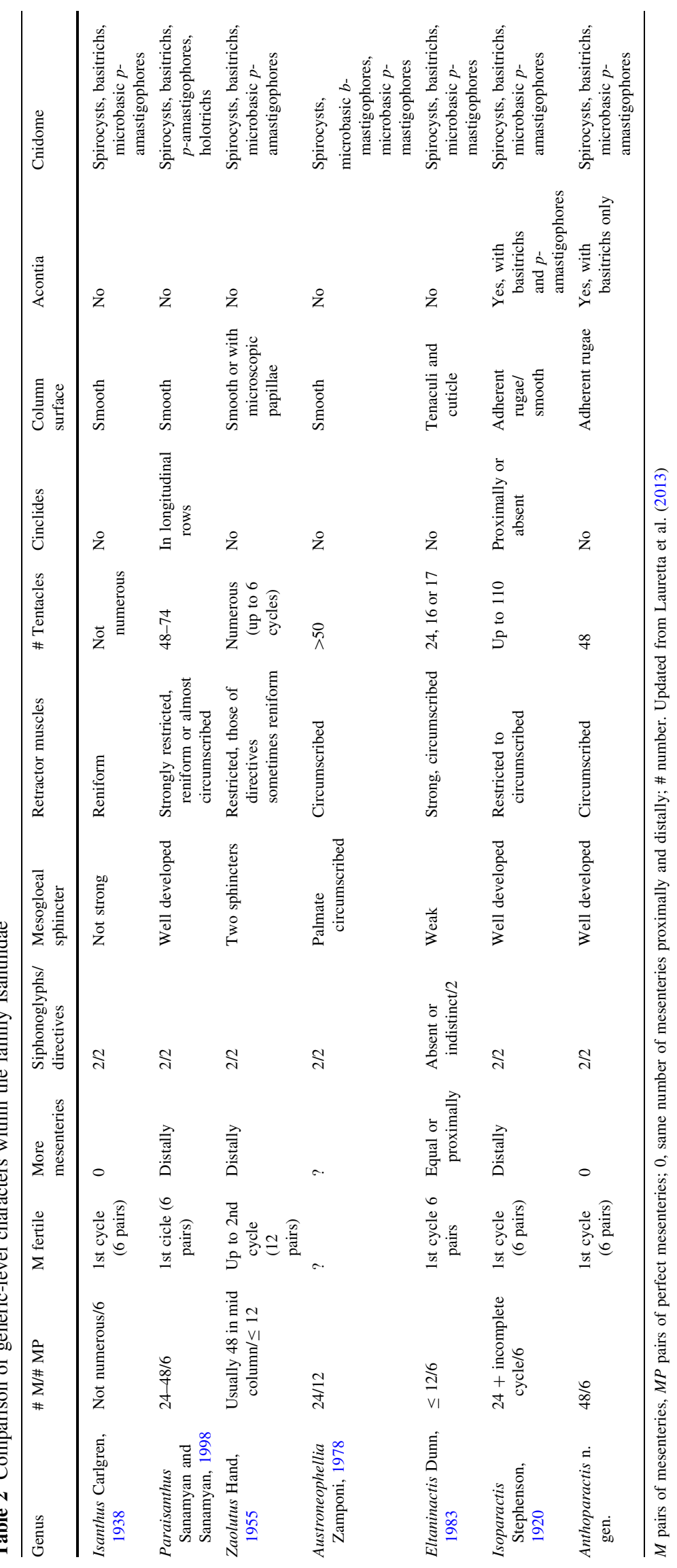


Fig. 2c and Fig. 2b in Lauretta et al. 2013). Anthoparactis fossii $\mathrm{n}$. gen. et sp. and I. fionae differ in number of tentacles (48 vs. up to 68) and mesenteries distally and proximally (equal number vs. more mesenteries distally), colour pattern of the oral disc (brown with white lines $v s$. brown and whitish with pink ring around mouth opening), geographical distribution $\left(44-45^{\circ} \mathrm{S}\right.$ vs. $50-55^{\circ} \mathrm{S}$; both in Chile) and cnidae. Concerning cnidae, despite intense search in various specimens we did not find any microbasic $p$-amastigophores in the acontia of $A$. fossii n. gen. et sp. It also lacks spirocysts in the pedal disc and small basitrichs in the actinopharynx (all present in I. fionae); it has smaller microbasic $p$-amastigophores and a smaller size range of basitrichs in the filaments. The total range of both size ranges of basitrichs in the tentacles of $A$. fossii n. gen. et sp. agrees with the one, larger size range given for I. fionae (Lauretta et al. 2013).

Acknowledgments Many thanks to Günter Försterra for helping $\mathrm{VH}$ to collect the specimens in 2005 and for collecting the specimens in 2011. We thank Mercer Brugler (AMNH) for obtaining molecular data. Many thanks to Carlos Spano, Katherine McLean and Ulrich Pörschmann for help with the cnidae examinations; Ulrich Pörschmann made the map in Fig. 1 and helped calculate cnidae statistics; Kaitlin McConnell proofread preliminary scripts. We are grateful to NAVIMAG who provided logistic support in 2011 and 2014. Thanks to CONAF for letting us use their vessel Petrel to navigate through the Chonos Archipielago in 2011 and to Keri and Greg to support us in 2014 with their vessel Saoirse. The study was partially funded through the Pew Charitable Trust and Fondecyt project Nr. 1131039. This is publication Nr. 97 of Huinay Scientific Field Station.

Ethical standard The experiments comply with the current laws of Chile.

\section{References}

Carlgren O (1893) Studien über Nordische Actinien. K Svenska Vetenskapsakad Handl 25:1-148

Carlgren O (1938) South African Actiniaria and Zoantharia. K Svenska Vetenskapsakad Handl 17:1-148
Dunn DF (1983) Some antarctic and sub-antarctic sea anemones (Coelenterata: Ptychodactiaria and Actiniaria). Biol Antarct Seas XIV Antarct Res Ser 39:1-67

Gabe M (1968) Technique Histologique. Massouet et Cie, Paris

Hand C (1955) The Sea Anemones of Central California Part II. The Endomyarian and Mesomyarian anemones. Wasmann J Biol 13:37-99

Häussermann V, Försterra G (2008) A new species of sea anemone from the Chilean fjord region, Paraisanthus fabiani (Actiniaria: Isanthidae), with a discussion of the family Isanthidae Carlgren, 1938. Zootaxa 1897:27-42

Humason G (1967) Animal tissue techniques. WH Freeman and Company, San Francisco

Lauretta D, Häussermann V, Brugler MR, Rodríguez E (2013) Isoparactis fionae sp. nov. (Cnidaria: Anthozoa: Actiniaria) from Southern Patagonia with a discussion of the family Isanthidae. Org Divers Evol. doi:10.1007/s13127-013-0149-z

Mariscal R (1974) Nematocysts. In: Muscatine L, Lenhoff HM (eds) Coelenterate biology. Reviews and new perspectives. Academic Press, New York, pp 129-178

Rodríguez E, Barbeitos M, Brugler MR, Crowley L, Gusmão L, Häussermann V, Grajales A, Daly M (2014) Hidden among sea anemones: the first comprehensive phylogenetic reconstruction of the order Actiniaria (Cnidaria, Anthozoa, Hexacorallia) reveals a novel group of hexacorals. PLoS ONE 9(5):e96998. doi:10.1371/journal.pone.0096998

Sanamyan NP, Sanamyan KE (1998) Some Actiniaria from the Commander Islands (Cnidaria: Anthozoa). Zoosyst Rossica $7: 1-8$

Schmidt H (1969) Die Nesselkapseln der Aktinien und ihre differentialdiagnostische Bedeutung. Helgol Wiss Meeres 19:284-317

Stephenson TA (1920) On the classification of Actiniaria. Part I.Forms with acontia and forms with a mesogloeal sphincter. Q J Microsc Sci 64:425-574

Stephenson TA (1928) The British sea anemones, vol 1. The Ray Society Dulau \& Co, Ltd, London

Stephenson TA (1935) The British Sea Anemones, vol 2. Dulau \& Co, Ltd, London

Stuckey F (1909) A review of the New Zealand Actiniaria known to science, together with a description of twelve new species. Trans New Zealand Inst 41:374-398

Zamponi MO (1978) La anemonofauna de Mar del Plata y localidades vecinas II. La anemonas Mesomyaria (Coelenterata: Actiniaria). Neotropica 24:21-26 